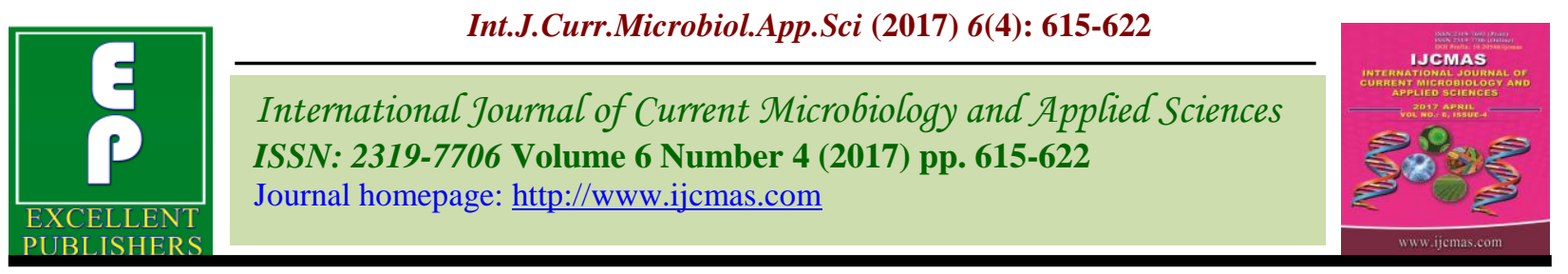

Original Research Article

https://doi.org/10.20546/ijcmas.2017.604.074

\title{
Management of Sucking Pests by Using Newer Insecticides and their Effect on Natural Enemies in Tomato (Lycopersicon esculentum Mill.)
}

\author{
B.M. Wagh*, K.S. Pagire, Dipali P. Thakare and A.B. Birangal \\ Department of Agricultural Entomology, Mahatma Phule Krishi Vidyapeeth, \\ Rahuri-413 722, Ahmednagar (MS), India \\ *Corresponding author
}

\begin{tabular}{|c|c|}
\hline & A B S T R A C T \\
\hline $\begin{array}{l}\text { Lycopersicon } \\
\text { esculentum Mill., } \\
\text { new insecticides, } \\
\text { Aphis gossypii, } \\
\text { Bemecia tabaci, } \\
\text { Frankliniella } \\
\text { schultzei. }\end{array}$ & \multirow{3}{*}{ 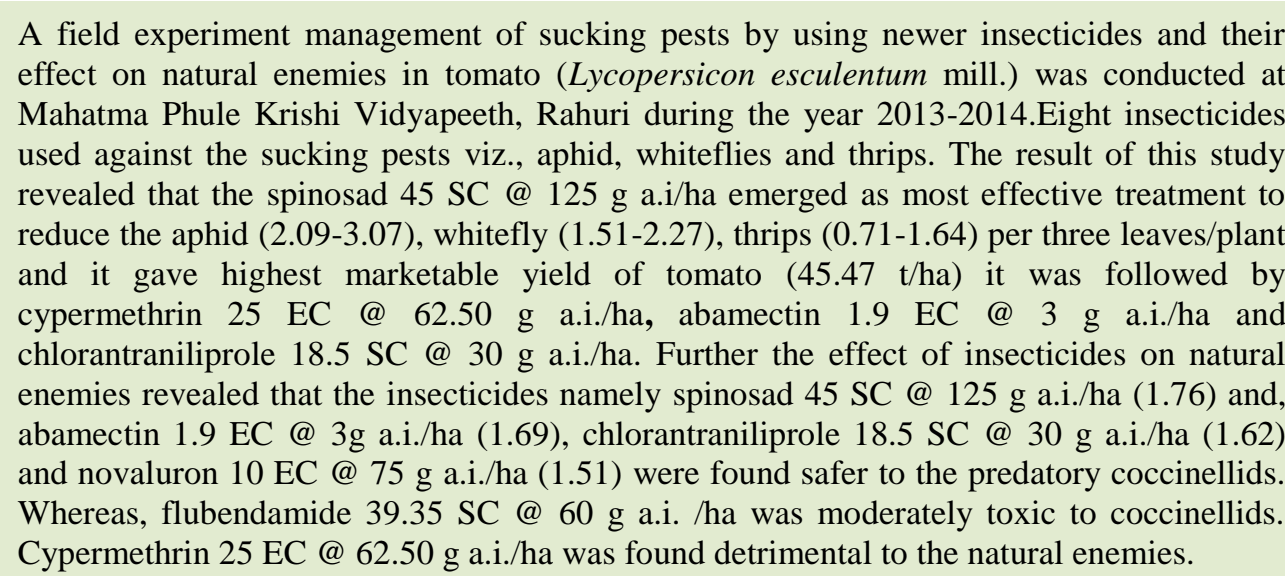 } \\
\hline Article Info & \\
\hline $\begin{array}{l}\text { Accepted: } \\
\text { 06 March } 2017 \\
\text { Available Online: } \\
10 \text { April } 2017\end{array}$ & \\
\hline
\end{tabular}

\section{Introduction}

Tomato (Lycopersicon esculentum Mill.) is one of the most popular solanaceous vegetable crops grown all over the world and ranks second in importance after potato. In India, tomato is cultivated in almost all parts of the country and occupy an area of about 8.79 lakh hectares with total production of 182.27 lakh MT and productivity of 20.7 MT/ha (Anonymous, 2013). In Maharashtra, tomato is cultivated over an area of about 0.50 lakh hectares with production of 10.50 lakh tones and the productivity is 21.0 tones/ha (Anonymous, 2013). Tomato growers in Western Maharashtra regularly experienced the economic damage caused by fruit borer (Helicoverpa armigera Hubner), whitefly (Bemisia tabaci Gennadius), aphid (Aphis gossypii Glover) and thrips (Frankliniella schultzei Trybom). These pests are polyphagous in nature and their abundance in nature is throughout the year. Moreover, the cultivation of tomato and availability of alternate hosts encourage the development of pest pressure round the year. The sucking pests viz., thrips, whiteflies and aphids cause severe damage to crop by transmitting virus disease rather than direct feeding. 
In sucking pest complex, whitefly is important as it imparts direct damage to the crop by desaping and also acts as vector for transmission of leaf curl virus disease in tomato (De Barro, 1995; Jones, 2003). Yield losses due to direct and indirect damage caused by whiteflies were reported to the extent of 20 to 100 per cent (Papisarta and Garzia, 2002).

\section{Materials and Methods}

The field trial was conducted during rabi 2013-14 atAICRP on Vegetable crops, Department of Horticulture, MPKV, Rahuri, Dist: Ahmednagar laid out in RBD with nine treatment and three replications including untreated control. Seeds of hybrid tomato 'Namdhari-501' were used for sowing. Seedling was transplanted after one month in the plots having a size of $4.50 \times 4.05 \mathrm{~m}$ (gross plot) and $3 \times 3.15 \mathrm{~m}$ (net plot size) at spacing $75 \mathrm{~cm} \mathrm{x} 45 \mathrm{~cm}$ between plant to plant and row to row respectively. When on adequate population of sucking pests was grown up, the chemical were sprayed with knapsack sprayer as specific dosages. In trial in all three sprays were taken starting from 45 days after transplanting at 10 days interval. The sticker sandovit (1 ml/lit) was added in spray fluid before spraying in each insecticide. Application of insecticides was done by hand operated knapsack sprayer by using 500 liters of water/hector.

For recording observations, five plants were selected randomly from each treatment and tagged. On each selected plant, three leaves each from upper, middle and bottom portion were inspected from lower side for presence of sucking pests. In respect of whiteflies only nymphs were counted. However, nymphs as well as adults were recorded in respect of aphids, thrips by using the hand lenses of 10 magnifications. The count of coccinellids was recorded randomly on five plants per treatment plot. Pre-count was taken one day prior to each spray and subsequent counts were recorded at $3^{\text {rd }}, 7^{\text {th }}$ and $10^{\text {th }}$ day after the spray. Observations were recorded early in the morning before 8.00 a.m. as suggested by Mote (1977). The yield of marketable tomato fruits plucked at each picking was recorded separately for each treatment plot and computed yield data of eight pickings were converted into tonn /ha. The data on counts of aphids, thrips, whiteflies were converted to square root transformed values +0.5 i.e. $(\sqrt{n+0.5})$ where ' $n$ ' is the mean value of actual count of concerned pests.

\section{Results and Discussion}

\section{Efficacy of insecticidal treatments against sucking pests of tomato}

The data of average of three sprays are presented in table 1 .

\section{Aphids}

The treatment with spinosad 45 SC @ $125 \mathrm{~g}$ a.i. /ha at three days after sprays recorded least (2.09 aphids/plant) aphids and emerged as the most effective treatment over others. However, this treatment was at par with cypermethrin 25 EC @ 62.50 g a.i./ha (2.16), abamectin 1.9 EC @ 3 g a.i./ha (2.40) and chlorantraniliprole 18.5 SC @ $30 \mathrm{~g}$ a.i./ha (2.49 aphids/3 leaves/plant)were equally effective and significantly superior over untreated control. At seven days after spray, all the insecticidal treatments were significantly superior over untreated control in reducing aphid population and recorded the average survival population in the range of 1.31 to 3.51 aphids/3 leaves/plant in various insecticide treatments as against 17.47 aphids in untreated control. The treatment with spinosad 45 SC @ $125 \mathrm{~g}$ a.i./ha recorded lowest (1.31 aphids/3 leaves/plant) population of aphid and emerged as the most effective treatment over remaining test insecticides. 
The treatment with spinosad 45 SC @ $125 \mathrm{~g}$ a.i./ha at ten days after spray recorded minimum of 3.07 aphids/3 leaves/plant and found most effective over other test insecticides except, cypermethrin 25 EC @ $62.50 \mathrm{~g}$ a.i./ha (3.13), abamectin 1.9 EC @ 3 g a.i./ha (3.24) and chlorantraniliprole 18.5 SC @ 30 g a.i./ha (3.38) (Fig. 1).

\section{Whiteflies}

The treatment with spinosad 45 SC @ $125 \mathrm{~g}$ a.i. /ha found very effective against whitefly during ten days after spray interval and recorded the whiteflies population in the range $(0.84-2.27$ whiteflies/3 leaves/plant $)$ as against $(12.11-13.31$ whiteflies/3 leaves/plant). Whereas the treatments of cypermethrin 25 EC @ $62.50 \mathrm{~g}$ a.i. /ha, abamectin 1.9 EC @ $3 \mathrm{~g}$ a.i. /ha and chlorantraniliprole 18.5 SC @ $30 \mathrm{~g}$ a.i. /ha were found at par with this treatment (Fig. 2).

\section{Thrips}

All the insecticidal treatments were significantly superior over untreated control. The treatment with spinosad45 SC @ $125 \mathrm{~g}$ a.i. /ha emerged as most effective treatment over other and recorded $(0.36-1.64$ thrips/3 leaves/plant) thrips population during the ten days spray interval. However the treatment with cypermethrin $25 \mathrm{EC}$ @ $62.50 \mathrm{~g}$ a.i. /ha, abamectin 1.9 EC @ 3 g a.i. /ha and chlorantraniliprole 18.5 SC @ 30 g a.i. /ha was found equally as that of this treatment and registered the average survival population of thrips in rang $0.44-2.00$ thrips $/ 3$ leaves/plant (Fig. 3). The present findings is in agreement with Kalawate and Dethe (2006), Raghuvanshi (2014) who recorded effectiveness of spinosad 45 SC @ $125 \mathrm{~g}$ a.i./ha and cypermethrin 25 EC @ $62.50 \mathrm{~g}$ a.i./ha against sucking pests. Sarangdevot et al., (2006) reported that cypermethrin showed better efficacy against whitefly on tomato.
The treatment with spinosad45 SC @ $125 \mathrm{~g}$ a.i./ha, and abamectin 1.9 EC @ $3 \mathrm{~g}$ a.i./ha were found effective treatments for controlling thrips, aphids and whiteflies and recorded significantly yield of tomato. Similar result of effectiveness of these insecticides against these pests was obtained earlier by Premachandra et al., (2005), Prabhatkumar and Poehling (2007) and Nazier (2008). The treatment with chlorantraniliprole 18.5 SC @ $30 \mathrm{~g}$ a.i./ha was found to be next effective treatment incontrolling Bemisia tabaci and in preventing transmission of the begomovirus Tomato yellow leaf curl virus (TYVMV). These results are confirmatory which has been recommended by Schuster et al., (2013).

The treatment with novaluron 10 EC @ $75 \mathrm{~g}$ a.i. /ha was noticed relative effective in reducing fruit borer and also affects nymphs of Bemisia tabaci population in present investigation. These observations are in conformity with those of Ishaaya et al., (2011) who reported novaluron affects nymphs of Bemisia tabaci more than chlorofluazuron and teflubenzurons. Earlier workers Christopher and Cynthia (2007), Raghvani and Posiya (2006); Cordero et al., (2006) and Ishaaya et al., (1996) reported as novaluron as better treatments for controlling sucking pests.

Efficacy of insecticidal treatments against coccinellids (Coccinella septempunctata L.) on tomato

The data in table 2 (Fig. 4) revealed that the population of lady bird beetle per five plants did not vary significantly at one day before spraying (pre-count) recording 3.80 to 4.27 LBB/five plants indicating their uniform distribution throughout the experimental plot. The coccinellids observed were Cheilomenes sexmaculatus (F.), Coccinella septempunctata (L.) among that Coccinella septempunctata (L.) was common in tomato field. 
Table.1 Effect of insecticidal treatments against sucking pests of tomato after sprays

\begin{tabular}{|c|c|c|c|c|c|c|c|c|c|c|}
\hline \multirow{2}{*}{ Treatment } & \multicolumn{3}{|c|}{$\begin{array}{c}\text { Av. number of } \\
\text { aphids/3 leaves/plant }\end{array}$} & \multicolumn{3}{|c|}{$\begin{array}{c}\text { Av. number of } \\
\text { white flies/3 leaves/plant }\end{array}$} & \multicolumn{3}{|c|}{$\begin{array}{c}\text { Av. number of } \\
\text { thrips/3 leaves/plant }\end{array}$} & \multirow[t]{2}{*}{$\begin{array}{l}\text { Yield } \\
(\mathrm{t} / \mathrm{ha})\end{array}$} \\
\hline & 3 DAS & 7 DAS & 10 DAS & 3 DAS & 7 DAS & 10 DAS & 3 DAS & 7 DAS & 10 DAS & \\
\hline $\begin{array}{l}\text { Chlorantraniliprole } 18.5 \mathrm{SC} \\
@ 30 \mathrm{~g} \text { a.i./ha }\end{array}$ & $\begin{array}{c}2.49 \\
(1.66)\end{array}$ & $\begin{array}{l}1.78 \\
(1.44)\end{array}$ & $\begin{array}{c}3.38 \\
(1.93)\end{array}$ & $\begin{array}{l}1.80 \\
(1.44)\end{array}$ & $\begin{array}{l}1.07 \\
(1.21)\end{array}$ & $\begin{array}{c}2.60 \\
(1.70)\end{array}$ & $\begin{array}{c}1.00 \\
(1.20)\end{array}$ & $\begin{array}{l}0.60 \\
(1.04)\end{array}$ & $\begin{array}{c}2.00 \\
(1.57)\end{array}$ & 46.03 \\
\hline $\begin{array}{l}\text { Flubendamide } 39.35 \mathrm{SC} \\
\text { @ } 60 \mathrm{~g} \text { a.i./ha }\end{array}$ & $\begin{array}{l}4.38 \\
(2.16)\end{array}$ & $\begin{array}{c}3.16 \\
(1.86)\end{array}$ & $\begin{array}{l}5.40 \\
(2.41)\end{array}$ & $\begin{array}{c}3.82 \\
(2.06)\end{array}$ & $\begin{array}{c}2.73 \\
(1.76)\end{array}$ & $\begin{array}{l}4.80 \\
(2.28)\end{array}$ & $\begin{array}{c}2.56 \\
(1.73)\end{array}$ & $\begin{array}{l}1.76 \\
(1.49)\end{array}$ & $\begin{array}{c}3.24 \\
(1.92)\end{array}$ & 44.86 \\
\hline $\begin{array}{l}\text { Emamectin benzoate } 5 \mathrm{SG} \\
\text { @ } 10 \mathrm{~g} \text { a.i./ha }\end{array}$ & $\begin{array}{l}4.56 \\
(2.21)\end{array}$ & $\begin{array}{c}3.38 \\
(1.92)\end{array}$ & $\begin{array}{l}5.60 \\
(2.45)\end{array}$ & $\begin{array}{l}4.00 \\
(2.10)\end{array}$ & $\begin{array}{c}2.91 \\
(1.81)\end{array}$ & $\begin{array}{l}4.93 \\
(2.31)\end{array}$ & $\begin{array}{l}2.76 \\
(1.79)\end{array}$ & $\begin{array}{l}1.96 \\
(1.56)\end{array}$ & $\begin{array}{l}3.40 \\
(1.96)\end{array}$ & 40.21 \\
\hline $\begin{array}{l}\text { Spinosad } 45 \mathrm{SC} \\
@ 125 \mathrm{~g} \text { a.i./ha }\end{array}$ & $\begin{array}{c}2.09 \\
(1.53)\end{array}$ & $\begin{array}{c}1.31 \\
(1.28)\end{array}$ & $\begin{array}{c}3.07 \\
(1.85)\end{array}$ & $\begin{array}{c}1.51 \\
(1.33)\end{array}$ & $\begin{array}{c}0.84 \\
(1.11)\end{array}$ & $\begin{array}{l}2.27 \\
(1.60)\end{array}$ & $\begin{array}{c}0.71 \\
(1.07)\end{array}$ & $\begin{array}{c}0.36 \\
(0.91)\end{array}$ & $\begin{array}{c}1.64 \\
(1.45)\end{array}$ & 45.47 \\
\hline $\begin{array}{l}\text { Indoxacarb } 14.5 \text { SC } \\
@ 40 \mathrm{~g} \text { a.i./ha }\end{array}$ & $\begin{array}{c}4.67 \\
(2.23)\end{array}$ & $\begin{array}{c}3.51 \\
(1.96)\end{array}$ & $\begin{array}{c}5.76 \\
(2.48)\end{array}$ & $\begin{array}{l}4.18 \\
(2.14)\end{array}$ & $\begin{array}{c}3.04 \\
(1.85)\end{array}$ & $\begin{array}{l}5.09 \\
(2.35)\end{array}$ & $\begin{array}{l}2.98 \\
(1.85)\end{array}$ & $\begin{array}{c}2.16 \\
(1.62)\end{array}$ & $\begin{array}{l}3.62 \\
(2.02)\end{array}$ & 34.92 \\
\hline $\begin{array}{l}\text { Abamectin } 1.9 \mathrm{EC} \\
\text { @ } 3 \mathrm{~g} \text { a.i./ha }\end{array}$ & $\begin{array}{c}2.40 \\
(1.63)\end{array}$ & $\begin{array}{c}1.60 \\
(1.38)\end{array}$ & $\begin{array}{c}3.24 \\
(1.90)\end{array}$ & $\begin{array}{l}1.67 \\
(1.40)\end{array}$ & $\begin{array}{c}0.98 \\
(1.17)\end{array}$ & $\begin{array}{l}2.44 \\
(1.66)\end{array}$ & $\begin{array}{c}0.89 \\
(1.15)\end{array}$ & $\begin{array}{l}0.53 \\
(1.01)\end{array}$ & $\begin{array}{l}1.89 \\
(1.53)\end{array}$ & 33.86 \\
\hline $\begin{array}{l}\text { Novaluron } 10 \mathrm{EC} \\
\text { @ } 75 \mathrm{~g} \text { a.i./ha }\end{array}$ & $\begin{array}{l}4.24 \\
(2.13)\end{array}$ & $\begin{array}{c}3.02 \\
(1.83)\end{array}$ & $\begin{array}{l}5.29 \\
(2.38)\end{array}$ & $\begin{array}{c}3.67 \\
(2.02)\end{array}$ & $\begin{array}{c}2.62 \\
(1.73)\end{array}$ & $\begin{array}{l}4.62 \\
(2.24)\end{array}$ & $\begin{array}{l}2.22 \\
(1.64)\end{array}$ & $\begin{array}{c}1.44 \\
(1.39)\end{array}$ & $\begin{array}{c}3.04 \\
(1.87)\end{array}$ & 44.00 \\
\hline $\begin{array}{l}\text { Cypermethrin } 25 \mathrm{EC} \\
\text { @ } 62.50 \mathrm{~g} \text { a.i./ha }\end{array}$ & $\begin{array}{c}2.16 \\
(1.56)\end{array}$ & $\begin{array}{l}1.40 \\
(1.32)\end{array}$ & $\begin{array}{c}3.13 \\
(1.87)\end{array}$ & $\begin{array}{l}1.60 \\
(1.37)\end{array}$ & $\begin{array}{c}0.89 \\
(1.12)\end{array}$ & $\begin{array}{l}2.36 \\
(1.63)\end{array}$ & $\begin{array}{c}0.78 \\
(1.10)\end{array}$ & $\begin{array}{c}0.44 \\
(0.96)\end{array}$ & $\begin{array}{l}1.80 \\
(1.50)\end{array}$ & 33.00 \\
\hline Untreated control & $\begin{array}{l}16.73 \\
(4.15)\end{array}$ & $\begin{array}{l}17.47 \\
(4.23)\end{array}$ & $\begin{array}{l}18.20 \\
(4.32)\end{array}$ & $\begin{array}{l}12.11 \\
(3.55)\end{array}$ & $\begin{array}{l}12.89 \\
(3.65)\end{array}$ & $\begin{array}{l}13.31 \\
(3.71)\end{array}$ & $\begin{array}{c}9.69 \\
(3.17)\end{array}$ & $\begin{array}{l}10.33 \\
(3.27)\end{array}$ & $\begin{array}{l}11.44 \\
(3.44)\end{array}$ & 28.04 \\
\hline S.E. m. \pm & 0.15 & 0.15 & 0.14 & 0.16 & 0.13 & 0.14 & 0.15 & 0.14 & 0.14 & 1.47 \\
\hline C.D. at $5 \%$ & 0.45 & 0.46 & 0.42 & 0.46 & 0.40 & 0.42 & 0.46 & 0.41 & 0.41 & 4.42 \\
\hline
\end{tabular}

DAS: Days after spray, ${ }^{*}$ Figures in parentheses are $\sqrt{\mathbf{n}+\mathbf{0 . 5}}$ transformed values 
Table.2 Cumulative effect of insecticidal treatments on coccinellid beetles in tomato (Average of three sprays)

\begin{tabular}{|c|c|c|c|c|}
\hline \multirow{2}{*}{$\begin{array}{l}\text { Sr. } \\
\text { No. }\end{array}$} & \multirow[t]{2}{*}{ Treatment } & \multicolumn{3}{|c|}{$\begin{array}{c}\text { Av. Population of } \\
\text { coccinellid beetles/5 plants }\end{array}$} \\
\hline & & 3 DAS & 7 DAS & 10 DAS \\
\hline 1 & Chlorantraniliprole 18.5 SC @ $30 \mathrm{~g}$ a.i./ha & $\begin{array}{c}1.44 \\
(1.38)\end{array}$ & $\begin{array}{c}0.87 \\
(1.16)\end{array}$ & $\begin{array}{c}1.62 \\
(1.45)\end{array}$ \\
\hline 2 & Flubendamide 39.35 SC @60 g a.i./ha & $\begin{array}{c}1.18 \\
(1.28)\end{array}$ & $\begin{array}{c}0.67 \\
(1.08)\end{array}$ & $\begin{array}{c}1.20 \\
(1.30)\end{array}$ \\
\hline 3 & Emamectin benzoate 5 SG @ $10 \mathrm{~g}$ a.i./ha & $\begin{array}{c}1.04 \\
(1.22)\end{array}$ & $\begin{array}{c}0.45 \\
(1.00)\end{array}$ & $\begin{array}{c}1.07 \\
(1.25)\end{array}$ \\
\hline 4 & Spinosad 45 SC @ $125 \mathrm{~g}$ a.i./ha & $\begin{array}{c}1.58 \\
(1.43)\end{array}$ & $\begin{array}{c}0.97 \\
(1.22)\end{array}$ & $\begin{array}{c}1.76 \\
(1.50)\end{array}$ \\
\hline 5 & Indoxacarb14.5 SC @ $40 \mathrm{~g}$ a.i./ha & $\begin{array}{c}0.67 \\
(1.15)\end{array}$ & $\begin{array}{c}0.44 \\
(0.96)\end{array}$ & $\begin{array}{c}0.93 \\
(1.19)\end{array}$ \\
\hline 6 & Abamectin 1.9 EC @3 g a.i./ha & $\begin{array}{l}1.08 \\
(1.40)\end{array}$ & $\begin{array}{c}0.93 \\
(1.19)\end{array}$ & $\begin{array}{c}1.69 \\
(1.48)\end{array}$ \\
\hline 7 & Novaluron 10 EC @ 75 g a.i./ha & $\begin{array}{c}1.33 \\
(1.34)\end{array}$ & $\begin{array}{c}0.80 \\
(1.13)\end{array}$ & $\begin{array}{c}1.51 \\
(1.41)\end{array}$ \\
\hline 8 & Cypermethrin 25 EC @ $62.50 \mathrm{~g}$ a.i./ha & $\begin{array}{c}0.76 \\
(1.09)\end{array}$ & $\begin{array}{c}0.36 \\
(0.92)\end{array}$ & $\begin{array}{c}0.73 \\
(1.10)\end{array}$ \\
\hline 9 & Untreated control & $\begin{array}{c}5.87 \\
(2.51) \\
\end{array}$ & $\begin{array}{c}6.31 \\
(2.60) \\
\end{array}$ & $\begin{array}{c}6.78 \\
(2.69) \\
\end{array}$ \\
\hline & S.E. m. \pm & 0.10 & 0.08 & 0.07 \\
\hline & C.D. at $5 \%$ & 0.30 & 0.24 & 0.22 \\
\hline
\end{tabular}

DAS: Days after spray, ${ }^{*}$ Figures in parentheses are $\sqrt{\mathbf{n}+\mathbf{0 . 5}}$ transformed values

Fig.1 Effect of newer insecticides against aphids (A. gossypii) on tomato (Average of three sprays)

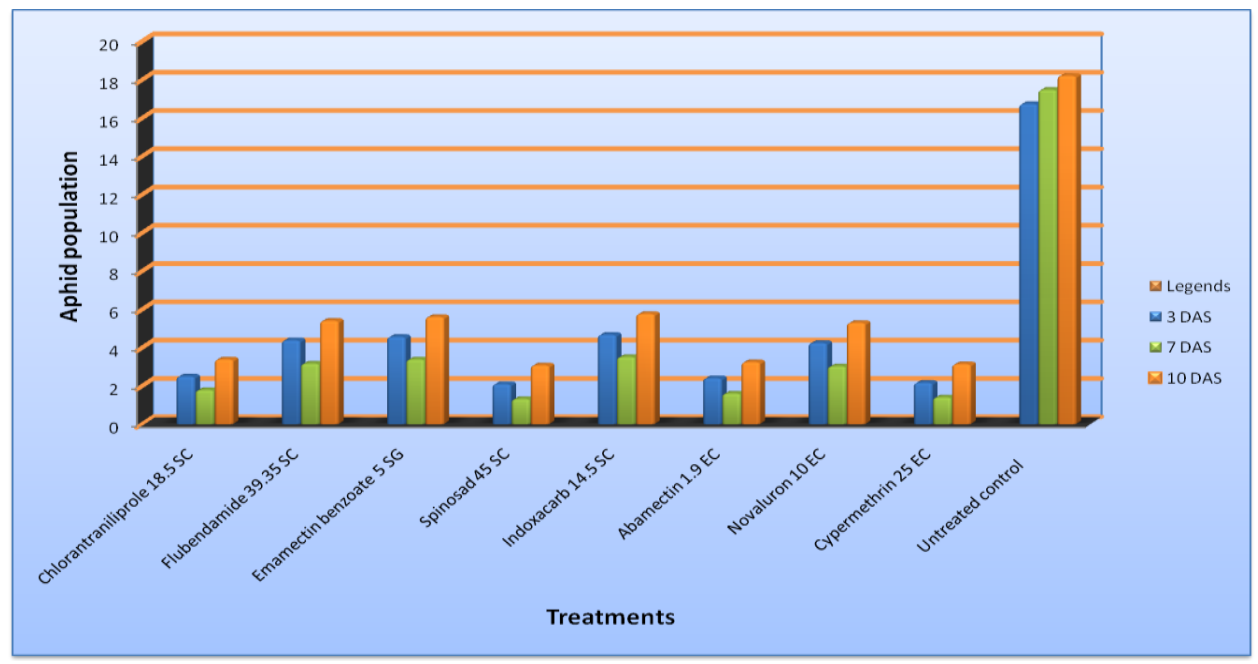


Fig.2 Effect of newer insecticides against whiteflies (B. tabaci) on tomato (Average of three sprays)

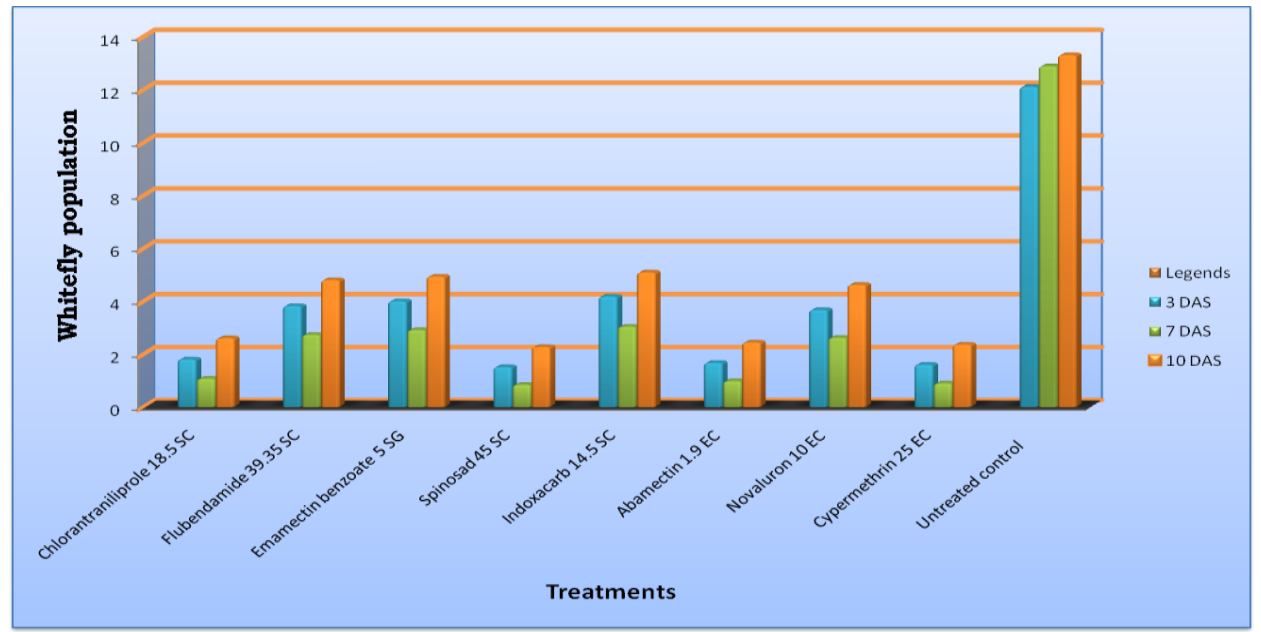

Fig.3 Effect of newer insecticides against thrips (F. schultzei) on tomato (Average of three sprays)

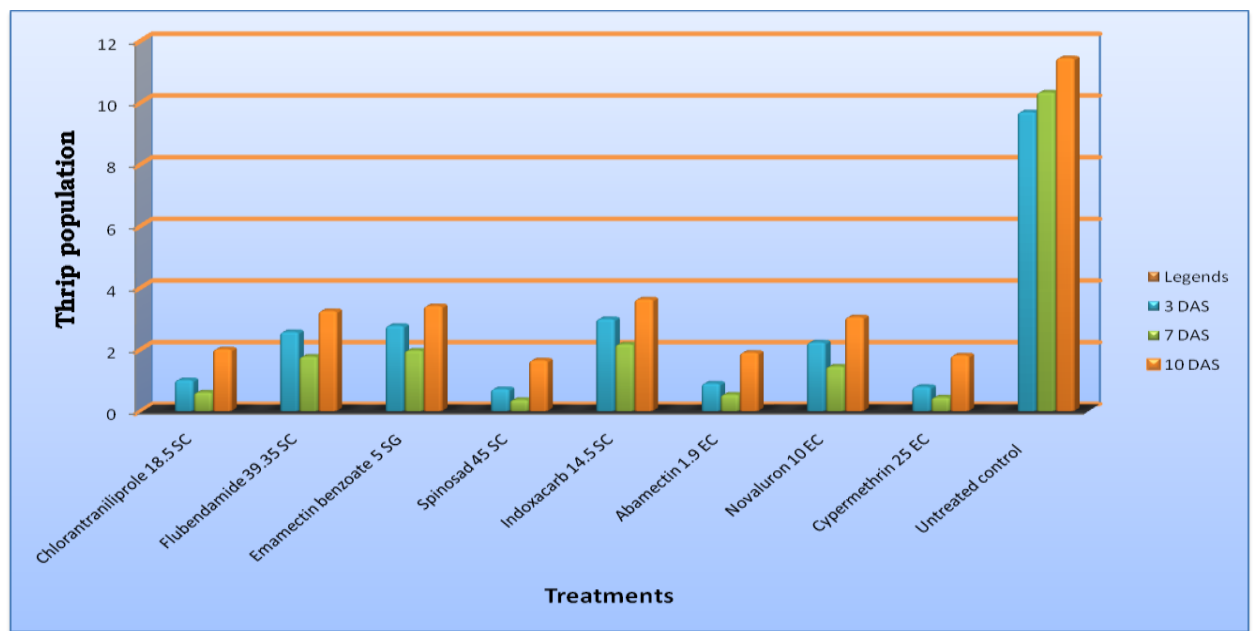

Fig.4 Effect of insecticidal treatments on coccinellid beetles in tomato (Average of three sprays)

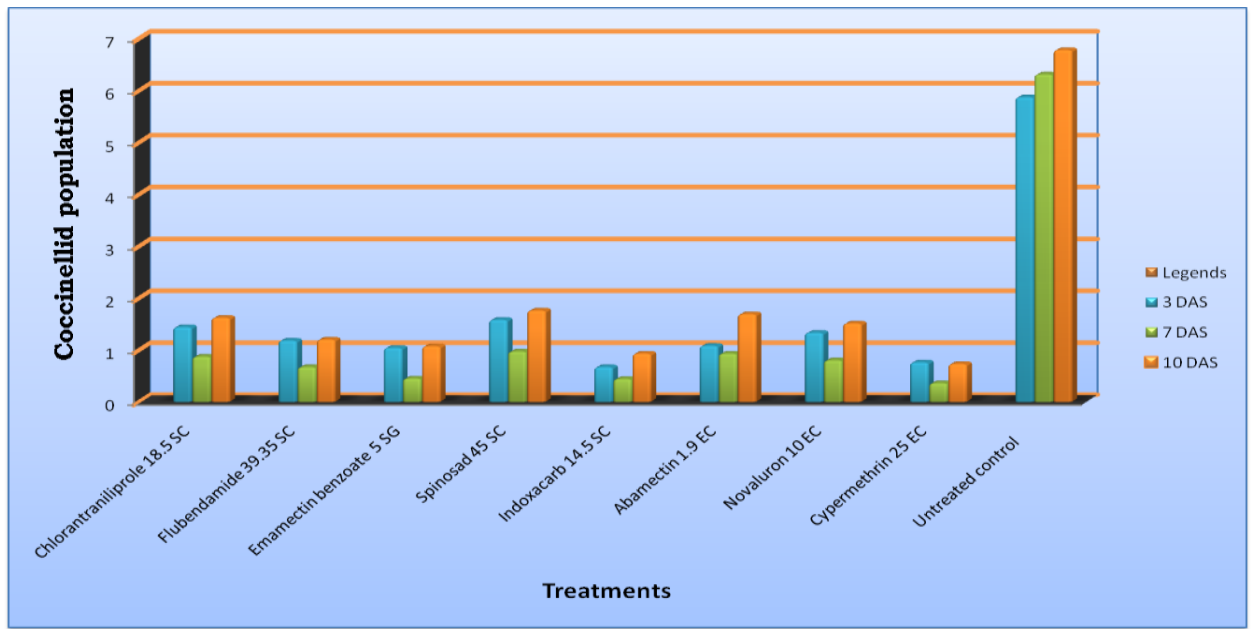


All the insecticidal treatments excluding, the treatment with indoxacarb 14.5 SC @ 40 g a.i./ha and cypermethrin 25 EC @ 62.50 g a.i./ha were found equally in cumulative effect at third days after spray and observed the population of coccinellids in the range (1.041.58 beetles) as against ( 5.87 beetles $/ 5$ plant) in untreated control. In cumulative impact on natural enemies at seventh and ten days after spray in the treatments with spinosad 45 SC @ $125 \mathrm{~g}$ a.i./ha, abamectin 1.9 EC @ $3 \mathrm{~g}$ a.i./ha, chlorantraniliprole 18.5 SC @ 30 g a.i./ha, novaluron $10 \quad$ EC @ 75 g a.i./ha and flubendamide 39.35 SC @ $60 \mathrm{~g}$ a.i./ha was found more or less similar in all the treatments and are safest insecticides recorded the coccinellids population in the range 0.67 to 0.98 beetles $/ 5$ plants and 1.20 to 1.76 beetles $/ 5$ plants as against (6.31) and (6.78) beetles/5 plants in untreated control, respectively. The cumulative data on the abundance of coccinellids per five plants recorded for three sprays and it was revealed from that the treatment with cypermethrin was found to be the most toxic to predatory spiders while spinosad appeared to be the safest recording highest population of coccinellids ( 0.97 to 1.76$)$ to that recorded in untreated plot (5.87to 6.78) per five plant. Similar observations in respect of spinosad were also reported by earlier research workers like Duffle et al., (1997); Murray and Lioyd (1997); Miles and Dutton (2000) and Medina et al., (2002) reported that spinosad exhibited marginal to excellent selectivity to lady bird beetle.

Efficacy of novaluron also safer to natural enemies recommended by Murthy et al., (2009), in the present study, the plot treated with cypermethrin 25 EC @ $62.50 \mathrm{~g}$ a.i./ha recorded least number of coccinellids per five plants. These results are in agreement with the earlier reports in respect of synthetic pyrethroids including cypermethrin causing higher mortality of spiders and other beneficial reported by Duffle et al., (1997) and Murray and Lioyd (1997). The result of this study provided the useful information that the spinosad 45 SC @
$125 \mathrm{~g}$ a.i/ha emerged as most effective treatment to reduce the aphid(2.09-3.07), whitefly (1.51-2.27), thrips (0.71-1.64) per three leaves/plant and it gave highest marketable yield of tomato $(45.47 \mathrm{t} / \mathrm{ha})$ it was followed by cypermethrin 25 EC @ 62.50 g a.i./ha, abamectin 1.9 EC @ 3 g a.i./ha and chlorantraniliprole 18.5 SC @ 30 g a.i./ha. Secondly the insecticides namely spinosad 45 SC @ 125 g a.i./ha (1.76) and, abamectin 1.9 EC @ 3g a.i./ha (1.69), chlorantraniliprole 18.5 SC @ $30 \mathrm{~g}$ a.i./ha (1.62) and novaluron $10 \mathrm{EC}$ @ $75 \mathrm{~g}$ a.i./ha (1.51) were found safer to the predatory coccinellids. Whereas, flubendamide 39.35 SC@60 g a.i. /ha was moderately toxic to coccinellids. Cypermethrin 25 EC @ $62.50 \mathrm{~g}$ a.i. /ha was found detrimental to the natural enemies.

\section{References}

Anonymous. 2013. National Horticulture Board, Govt. of India, publication page, 177-185.

Christopher, G., Cutler and Cynthia, D. Scott Dupree. 2007. Novaluron: prospects and limitations in Insect Pest Management. Pest Technol., Global Sci. Books.

Cordero, R.J., Kuhar, T.P., Speese, I.J., Youngman, R.R., Bloomquist, J.R., Kok, L.T. and Bratsch, A.D. 2006. Field efficacy of insecticides for control of lepidopteran pests on collards in virginia. Plant Health Progress.

De Barro, J.P. 1995. Bemisia tabaci biotype B: A review of its biology, distribution and control. Second ed., Division of Entomol., Technical Paper No. 36 CSIRO, Canberra, Australia.

Duffle, W., Sullivan, M.J. and Turnipseed, S.G. 1997. Survival of beneficial arthropods following the application of various insecticides. In: proceedings belt wide cotton conferences, National Cotton Council, Memphis, USA. 2: 1120-1121.

Ishaaya, I., Yablonski, S., Mendelson, Z., Mansour, Y. and Horowitz, A.R. 1996. Novaluron (MCW-275), a novel benzoylphenyl urea, suppressing developing stages of lepidopteran, whitefly and leaf miner pests. Proceedings of the 
bright on Crop Prot. Conference, Pests and Diseases, 3: 1013-1020.

Ishaaya, I., Lebedev, G., Ghanim, M. and Horowitz, A.R. 2011. Biorational control of arthropod pests with emphasis on the use of the chitin synthesis inhibitor novaluron. Pestrol., (1/4) Warsaw Institute of Industrial Organic Chemistry, 17-22.

Jones. 2003. Plant virus transmitted by whitefly. European J. Pl. Prot., 109: 195-219.

Kalawate, A. and Dethe, M.D. 2006. Bioefficacy study of biorational insecticide on brinjal. $J$. Biopest., 5(1): 75-80.

Medina, P., Budina, F., Vogt, H., Estal, P. del., Vinuela, E. and del-Estal, P. 2002. Preliminary assays on the influence of the ingestion of prey contaminated with three modern insecticides on C. cornea (Stephens) (Neuroptera: Chrysopidae). Boletin-de- sanidad, Vegetal, Plagas, 28(3): 375-384.

Miles, M. and Dutton, R. 2000. Spinosad a naturally derived insect control agent with potential for use in integrated pest management systems in greenhouse. In: proceedings the International $B C P C$ Conference, Brighton, UK. 1: 339-344.

Mote, U.N. 1977. Active and feeding period of onion thrips and proper time of application of endosulfan for their control. Veg. Sci., 5(2): 143-144.

Murray, D.A.H. and Lioyd, R.J. 1997. The effect of spinosad (Tracer) on arthropod pest and beneficial population in Australian cotton. In: proceedings belt wide cotton conferences, National Cotton Council, Memphis, USA. 2: 1087-1091.

Murthy, K.S., Reddy, R.K. and Yogi, K. 2009. Efficacy of certain eco friendly pesticide against citrus butterfly. Indian J. Pl. Prot., Vol.37(1 \& 2): 46-49.

Najir, T. 2008. Bio-efficacy of organic insecticide against aphids, Aphis gossypii (Glover) in
Bt cotton. Nation. Synop. on "Bt- cotton: opportunities and prospectus, pp. 22.

Papisarta, C. and Garzia, G.T. 2002. Tomato yellow leaf curl sordinia virus and its vector Bemisia tabaci in Sicillia (Italy) : Present status and control possibilities OEPP/EPPO Bull., 32 : 25-29.

Premachandra, D.W.T.S., Christian Borgemeister and Hans- Michael Poehling. 2005. Effects of neem and spinosad on Ceratothripoidesclaratris (Thysanoptera: Thripidae) an important vegetable pest in Thailand, under laboratory and greenhouse conditions.

Prabhatkumar and Poehling, H.M. 2007. Effects of azadirachtin, abamectin, and spinosad on sweet potato whitefly (Homoptera: Aleyrodidae) on tomato plants under laboratory and greenhouse conditions in the humid tropics. J. Econ. Ent., 100(2): 411420.

Raghvani, B.R. and Poshiya, Y.K. 2006. Field efficacy of newer insecticide against $H$. armigera (Hub) in chickpea. Pestol., 30(4): 18-20.

Raghuvanshi, S., Bhadauria, N.S. and Pradyumn Singh. 2014. Efficacy of insecticides against major insect pests of soybean [Glycine max Merrill]. Trends in biosci., 7(3): 191-193.

Sarangdevot, S.S., Ashok Kumar and Chundawat, G.S. 2006. Studies on bioefficacy of some newer insecticides against Bemisiatabaci and Amrascabiguttulabiguttulamon tomato in southern Rajasthan. Pestol., 30(5): 39-42.

Schuster, D.J., Natalia, A.P., Williams, R.W., Marcon, P.C. and Hector, E.P. 2013. Dupontrynaxypyr a novel anthranilamide insecticide for managing Bemisiatabaci and interfering with transmission of tomato yellow leaf curl virus on tomato transplants. J. Insect Sci., Vol. 8, Article4.

\section{How to cite this article:}

Wagh, B.M., K.S. Pagire, Dipali P. Thakare and Birangal, A.B. 2017. Management of Sucking Pests by Using Newer Insecticides and Their Effect on Natural Enemies in Tomato (Lycopersicon esculentum Mill.). Int.J.Curr.Microbiol.App.Sci. 6(4): 615-622. doi: https://doi.org/10.20546/ijcmas.2017.604.074 